RESEARCH NOTE

\section{A Survey of Freshwater} Gastropods in the Microrregião Serrana of the State of Rio de Janeiro, Brazil

\section{Silvana $\mathrm{C}$ Thiengo ${ }^{+}$, Monica $\mathrm{A}$ Fernandez, M Fernanda Boaventura, Marcelo A Stortti}

Departamento de Malacologia, Instituto Oswaldo Cruz, Av. Brasil 4365, 21045-900 Rio de Janeiro, RJ, Brasil

Key words: survey - Biomphalaria straminea Biomphalaria tenagophila - freshwater gastropods Rio de Janeiro - Brazil

In 1984 we received samples of freshwater gastropods from many localities of the State of Rio de Janeiro, sent by Fundação Nacional de Saúde for identification. In the past three years, aiming to elaborate a chart of planorbids of the State of Rio de Janeiro additional collecting was done by the authors in the area corresponding to the Microrregião Serrana of the state: Petrópolis, Teresópolis and São José do Vale do Rio Preto. The survey was extended to the neighbour towns, Guapimirim and Magé, in order to improve the knowledge of that poorly studied area.

The molluscs were collected from different suitable snail habitats: streams, rivers and marsh areas in the Atlantic forest as well as drainage and sewage ditches, wells, flood areas, ponds and irrigation canals.

Live snails were kept at the laboratory for a month in aquaria containing dechlorinated tap water and, at the bottom, a thin layer of a 2:1 mixture of screened reddish soil and ground oyster shells as a source of mineral nutrients. Snails were fed on fresh lettuce leaves. In the meantime specimens of Biomphalaria were exposed to artificial

\footnotetext{
This study was support by grants from Conselho Nacional de Pesquisas and Fundação de Amparo à Pesquisa do Estado do Rio de Janeiro.

${ }^{+}$Corresponding author. Fax: +55-21-280.5840

Received 4 May 1998

Accepted 31 August 1998
}

light in intervals of five days to determine possible infection with trematode larvae, mainly Schistosoma mansoni cercariae. The ten larger snails of each sample were preserved in Railliet-Henry's fluid after relaxation in a $0.05 \%$ nembutal solution and two of them were dissected under stereomicroscope for identification. Technical details were described elsewhere (SC Thiengo 1995 Técnicas Malacológicas, p. 255-265. In FS Barbosa, Tópicos em Malacologia Médica, Fiocruz, Rio de Janeiro). Samples of taxonomic importance were deposited at the Malacological Collection of Instituto Oswaldo Cruz/Fiocruz.

In all, 7 species of planorbids and 10 species of other freshwater gastropods were found in 15 localities at the studied area (Table): Antillorbis nordestensis (Lucena, 1954); Biomphalaria peregrina (Orbigny, 1835); Biomphalaria straminea (Dunker, 1848); Biomphalaria tenagophila (Orbigny, 1835); Drepanotrema anatinum (Orbigny, 1835); Drepanotrema cimex (Moricand, 1839); Drepanotrema lucidum (Pfeiffer, 1839); Ferrissia sp.; Gundlachia moricandi (Orbigny, 1837); Heleobia davisi Silva \& Thomé, 1985; Lymnaea columella (Say, 1817); Lymnaea sp.; Melanoides tuberculata (Müller, 1774); Physa cubensis Pfeiffer, 1839; Physa marmorata Guilding, 1828; Pomacea canaliculata (Lamarck, 1801); Pomacea sordida (Swainson, 1823).

Among the planorbid species B. tenagophila was the most frequent, occurring in 13 out of the 15 localities surveyed. According to WL Paraense (1986 Distribuição dos caramujos no Brasil, p. 117128. In FA Reis, I Faria \& N Katz (eds), Modernos Conhecimentos sobre Esquistossomose Mansônica, Biblioteca da Academia Mineira de Medicina, Belo Horizonte) it ranges from Caravelas

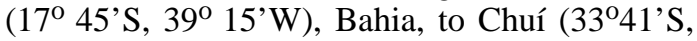
$53^{\circ} 27^{\prime} \mathrm{W}$ ), Rio Grande do Sul, following the littoral border, extending westwards at the States of São Paulo and Rio Grande do Sul .

$B$. straminea is the most widely spread of the three natural vectors of $S$. mansoni in the Western Hemisphere, since it ranges from Central America to South America east of the Andes, between $10^{\circ} \mathrm{N}$ at Costa Rica and $35^{\circ} \mathrm{S}$ at Argentina (WL Paraense 1983 Mem Inst Oswaldo Cruz 78: 343361). Concerning Rio de Janeiro, the data of the present paper extend its distribution (Table), since the previous records of this species are in the municipalities of Paracambi and Duque de Caxias (Paraense 1986 loc. cit.).

The municipalities of Guapimirim, Magé and Petrópolis presented two natural vectors of schistosomiasis, B. tenagophila and B. straminea. Biomphalaria peregrina, which may be considered a potential vector (WL Paraense \& LR Corrêa 1973 Rev Inst Med Trop São Paulo 15: 127-130) was 
also found in the latter municipality as well as in Teresópolis.

Although many different kinds of cercariae had been observed, no specimens were found infected with $S$. mansoni.

Up to now A. nordestensis had not been found in Rio de Janeiro. Its distribution comprises the states of Alagoas, Distrito Federal, Goiás, Maranhão, Minas Gerais, Pará, Paraná, Pernambuco, Rio Grande do Sul, Santa Catarina and São Paulo (WL Paraense 1975 Arq Mus Nac 55: 105-128).

The Asiatic thiarid M. tuberculata was introduced in the municipality of Guapimirim about thirty years ago by local fish raisers and became the dominant species in the tanks. Recently, albino specimens of Helisoma duryi (Wetherby, 1879), which do not occur naturally in Brazil, were found in the same municipality in aquaria of a fish raiser thus confirming that in spite of the ecological hazards from introduction of exotic species this situation is still occurring without any control.

Acknowledgements: to Regional Directory of Fundação Nacional de Saúde of Rio de Janeiro in 1984, for sending us samples of snails from several localities of the state and to Dr SB dos Santos (Instituto de Biologia, Universidade do Estado do Rio de Janeiro) for the identification of the ancylids. To Dr Roberto Magalhães Pinto (Departamento de Helmintologia, Instituto Oswaldo Cruz) for critically reading the manuscript.

\section{TABLE}

List of species and the localities where they were found in the surveyed area

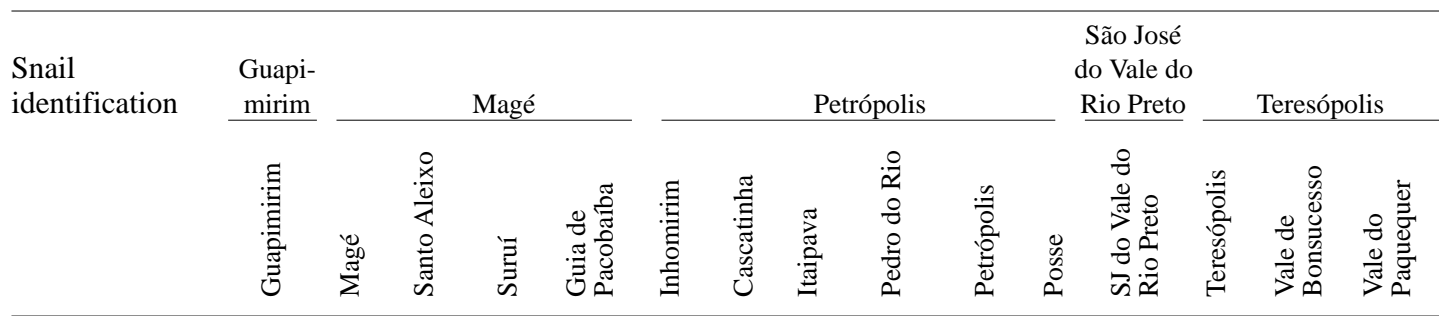



$a$ : only shells of young specimens available. 